ISSN 0258-7122

Bangladesh J. Agril. Res. 35(3) : 489-496, September 2010

\title{
GENOTYPE-ENVIRONMENT INTERACTION FOR COB YIELD AND MATURITY IN BABY CORN (Zea mays L.)
}

\author{
KAMRUN NAHAR ${ }^{1}$, S. AHMED ${ }^{2}$, M. A. L. AKANDA ${ }^{3}$ \\ M. A. A. MONDAL ${ }^{4}$ AND M. A. ISLAM ${ }^{5}$
}

\begin{abstract}
Genotype-location interaction and phenotypic stability of cob yield and maturity parameters of eight baby corn genotypes including hybrids and composite varieties were assessed during rabi 2006-2007. Significant genotypeenvironment interactions were observed for all the characters under study. Pooled deviations were also found significant for all the characters except days to harvesting. The genotype Khoibhutta was found stable for days to tasselling, days to harvesting and yield of by product and suited to unfavourable environment. On the other hand, the $\mathrm{BBC}_{1}$ was stable across environments for days to harvesting and cob yield. Genotype NS pop corn was stable for days to tasselling and suited to unfavourable environment and stable for yield of byproduct and cob yield across the environments. The genotype BHM5 showed stable performance only for cob yield across the environments.
\end{abstract}

Keywords: Stability, genotype, environment, $\mathrm{G} \times \mathrm{E}$, yield components, baby corn.

\section{Introduction}

Maize (Zea mays L.) is the third important cereal crop in Bangladesh. Recently, baby corn, the ear of the corn plant, harvested young when the silks have either emerged or just emerged $(1-3 \mathrm{~cm})$ with no fertilization is becoming popular in Bangladesh due to preparations of modern food items. However, there is no recommended baby corn variety for commercial cultivation in Bangladesh. Therefore, baby corn is being imported from different baby corn producing countries in the world spending a large amount of foreign currency. Currently, Breeding Division of Bangladesh Agricultural Research Institute (BARI) is trying to develop baby corn varieties locally having higher yield potentiality and adaptability over different agro-ecological zones of Bangladesh.

Stability of desirable genetic characters is important for development of improved varieties and useful for the commercial exploitation over a wide range of agro-climatic conditions. A commercial variety must have stable performance

\footnotetext{
${ }^{1 \& 2}$ Plant Breeding Division, Bangladesh Agricultural Research Institute (BARI), Gazipur, ${ }^{3}$ Regional Agricultural Research Station, Bangladesh Agricultural Research Institute (BARI), Ishurdi, Pabna, ${ }^{4}$ Regional Agricultural Research Station, Bangladesh Agricultural Research Institute (BARI), Burirhat, Rangpur, ${ }^{5}$ Regional Agricultural Research Station, Bangladesh Agricultural Research Institute (BARI), Hathazari, Chittagong, Bangladesh.
} 
and broad adaptation over a range of environments in addition to high yield potential. It is more practical to develop and release varieties which are adapted to more than a single environment and can be successfully grown over a range of environments. For this, a variety well adapted to more than one environment and stable has to be selected. Preliminary evaluation can be done to identify stable genotypes through screening. No trials have been initiated to test yield stability of baby corn in different climatic conditions in Bangladesh. The present study, therefore, has been designed to measure the relationship between genotypes and environment effects and to identify stable baby corn in respect of cob yield and maturity.

\section{Materials and Method}

The experiment was conducted at five locations of Bangladesh viz. Gazipur, Ishurdi, Burirhat, Hathazari, and Jamalpur during rabi 2006-2007. Eight hybrids and composite varieties, along with a commercial check, were evaluated in a randomized complete block design with three replications. The plot size was 2 rows of $5 \mathrm{~m}$ long for each entry spaced at $60 \times 20 \mathrm{~cm}$ between rows and hill. Fertilizers were applied @ 120, 80, 80, 20, and $5 \mathrm{~kg} / \mathrm{ha}$ of $\mathrm{N}, \mathrm{P}_{2} \mathrm{O}_{5}, \mathrm{~K}_{2} \mathrm{O}$, S and $\mathrm{Zn}$, respectively. All intercultural operations were done as and when necessary. Data on days to tasselling, days to harvesting of baby cob, yield of by-products ( $t / h a)$ and baby cob yields with husk cover (t/ha) were taken. Analysis of variance as well as pooled analysis of variance for different characters over the environments was done as suggested by Singh and Chaudhury (1979). Stability analysis was done using the model proposed by Eberhart and Russel (1966). According to this model, a stable genotype is one which shows (i) high mean, (ii) a regression coefficient (bi) around unity, and (iii) a mean square deviation from regression $\left(\mathrm{S}^{2} \mathrm{di}\right)$ near to zero.

\section{Results and Discussion}

Table 1 shows highly significant mean sum of squares for genotypes and environments for all the traits under study indicating the presence of substantial variation among the genotypes over environments and in the environmental mean over test genotypes. Although significant variation due to genotypes, environments and genotype-environment interaction for grain yield in maize have been reported earlier (Akanda et al., 2007; Guillen-Portal et al., 2003; Carvalho et al., 2000; Cardoso et al., 2000), but the effect of genotype and environments on cob yield is not available in Bangladesh and elsewhere. Genotypes also interacted significantly with environments for all the traits. Significant $G \times E$ interaction indicated that genotypes under different environments behaved differently for the expression of characters of interest. It means a particular variety may not exhibit the same phenotypic performance 
under different environments or different varieties may respond differently to a specific environment. The environment $+G \times E$ interactions were highly significant when tested against pooled error for all the characters which satisfied the requirement of stability analysis i.e., the genotypes interacted considerably with environments in the expression of the characters. Highly significant mean sum of squares due to environment (linear) for the traits indicated considerable differences among the environments and their predominant effects on the characters due to variations in weather conditions of different locations. Pixley and Bjamson (2002) reported significant environment (linear) for grain yield in maize. Variance due to $\mathrm{G} \times \mathrm{E}$ (linear) was non-significant for all the traits except days to harvesting. Roy et al. (1999) also observed non-significant $G \times E$ (linear) component for days to maturity and grain yield in maize. Variance due to pooled deviation was significant for all the characters except days to harvesting, indicating the major components of differences in stability due to the deviation from linearity and not the linear regression. The result confirms the findings of Sharma and Hore (1991).

Table 1. Pooled analysis of variance for different traits in eight baby corn genotypes.

\begin{tabular}{l|l|l|l|l|l}
\hline Source of variation & d. f. & $\begin{array}{c}\text { Days to } \\
\text { tasselling }\end{array}$ & $\begin{array}{c}\text { Days to } \\
\text { harvesting }\end{array}$ & $\begin{array}{c}\text { By-product } \\
\text { yield (t/ha) }\end{array}$ & $\begin{array}{c}\text { Yield of cob } \\
\text { with } \\
\text { husk cover } \\
\text { (t/ha) }\end{array}$ \\
\hline Variety(G) & 7 & $47.1 .0^{* *}$ & $22.44^{* *}$ & $68.64^{* *}$ & $5.76^{*}$ \\
Location(E) & 4 & $552.90^{* *}$ & $398.65^{* *}$ & $184.23^{* *}$ & $84.25^{* *}$ \\
G $\times$ E interaction & 28 & $5.26^{* *}$ & $6.90^{* *}$ & $14.36^{* *}$ & $1.70^{* *}$ \\
Location+(G×E) & 32 & $73.71^{* *}$ & $55.87^{* *}$ & $35.59^{* *}$ & $12.02^{* *}$ \\
Location linear & 1 & $2211.60^{* *}$ & $1594.59^{* *}$ & $736.93^{* *}$ & $337.00^{* *}$ \\
$(\mathrm{G} \times$ E) linear & 7 & $2.12 \mathrm{~ns}$ & $15.20^{* *}$ & $15.24 \mathrm{~ns}$ & $0.76 \mathrm{~ns}$ \\
Pooled deviation & 24 & $5.52^{* *}$ & $3.62 \mathrm{~ns}$ & $12.31^{* *}$ & $1.76^{* *}$ \\
Pooled error & 80 & 1.60 & 3.08 & 5.45 & 0.60 \\
\hline
\end{tabular}

* and ** significant at $5 \%$ and $1 \%$, respectively.

Table 2 presents the estimates of stability parameters viz., mean performance, regression coefficient (bi) and deviation from regression $\left(\mathrm{S}^{2} \mathrm{di}\right)$ of 8 baby corn genotypes for days to tasselling, days to harvesting, yield of by product and cob yield with husk cover. Eberhart and Russel (1966) suggested an ideal genotype as one having high mean performance, regression coefficient (bi) near unity and deviation from regression $\left(\mathrm{S}^{2} \mathrm{di}\right)$ near zero. Accordingly, in this study, these three parameters were considered simultaneously for identifying stable genotypes. However, in case of days to tasselling and harvesting, lower mean values along with stability parameters were considered for selecting early varieties. 
Table 2. Location-wise mean and estimated stability parameters for different traits in 8 baby corn genotypes.

\begin{tabular}{|c|c|c|c|c|c|c|c|c|c|c|c|c|c|c|c|c|}
\hline \multirow{3}{*}{ Varieties } & \multicolumn{8}{|c|}{ Days to tasselling } & \multicolumn{8}{|c|}{ Days to harvesting } \\
\hline & \multicolumn{5}{|c|}{ Location } & \multirow{2}{*}{ Mean } & \multirow{2}{*}{ bi } & \multirow{2}{*}{$\mathrm{S}^{2} \mathrm{di}$} & \multicolumn{5}{|c|}{ Location } & \multirow{2}{*}{ Mean } & \multirow{2}{*}{ bi } & \multirow{2}{*}{$S^{2} \mathrm{di}$} \\
\hline & $\mathrm{L}_{1}$ & $\mathrm{~L}_{2}$ & $\mathrm{~L}_{3}$ & $\mathrm{~L}_{4}$ & $\mathrm{~L}_{5}$ & & & & $\mathrm{~L}_{1}$ & $\mathrm{~L}_{2}$ & $\mathrm{~L}_{3}$ & $\mathrm{~L}_{4}$ & $\mathrm{~L}_{5}$ & & & \\
\hline BHM5 & 94.00 & 88.00 & 102.33 & 75.00 & 90.33 & 89.93 & 1.17 & $4.57^{*}$ & 96.00 & 99.33 & 107.33 & 80.00 & 94.00 & 95.33 & 1.41 & $-1.50 \mathrm{~ns}$ \\
\hline BBC2 & 90.67 & 86.00 & 100.33 & 75.67 & 83.67 & 87.27 & 1.07 & 3.33* & 92.67 & 94.33 & 108.00 & 80.67 & 90.33 & 93.20 & 1.35 & $5.10 \mathrm{~ns}$ \\
\hline Khoibhutta & 88.00 & 81.33 & 95.00 & 75.33 & 81.33 & 84.20 & 0.90 & $-0.07 \mathrm{~ns}$ & 90.67 & 91.67 & 98.33 & 79.67 & 89.00 & 89.87 & 0.95 & $-2.37 n s$ \\
\hline NS pop corn & 89.67 & 79.00 & 95.33 & 75.00 & 80.67 & 83.93 & 0.98 & $2.02 \mathrm{~ns}$ & 94.00 & 94.67 & 97.67 & 79.33 & 89.00 & 90.93 & 0.99 & $1.29 \mathrm{~ns}$ \\
\hline Shaita & 91.33 & 78.33 & 95.33 & 75.33 & 84.00 & 84.87 & 0.99 & $3.74 *$ & 93.67 & 90.33 & 98.00 & 87.33 & 89.00 & 91.67 & $0.53 *$ & $3.04 \mathrm{~ns}$ \\
\hline BBC1 & 87.67 & 77.00 & 94.67 & 74.33 & 84.00 & 83.53 & 0.96 & $3.24 *$ & 90.67 & 90.00 & 97.67 & 79.33 & 89.00 & 89.33 & 0.92 & $-1.78 n s$ \\
\hline BSCI & 85.33 & 76.00 & 93.67 & 74.33 & 79.33 & 81.73 & 0.92 & $3.72 *$ & 90.67 & 90.67 & 98.00 & 79.00 & 89.00 & 89.47 & 0.96 & $-2.14 n s$ \\
\hline $\begin{array}{l}\text { Pacific283 } \\
\text { (Check) }\end{array}$ & 93.67 & 90.67 & 99.67 & 75.33 & 91.00 & 90.07 & 1.01 & $13.32 * *$ & 94.67 & 97.67 & 97.33 & 81.00 & 94.00 & 92.93 & 0.89 & $7.58^{*}$ \\
\hline $\begin{array}{l}\text { Environmental } \\
\text { mean }\end{array}$ & 90.04 & 82.04 & 97.04 & 75.04 & 84.29 & 85.69 & - & - & 92.88 & 93.58 & 100.29 & 80.79 & 90.42 & 91.59 & - & - \\
\hline $\begin{array}{l}\text { Environmental } \\
\text { index (I) }\end{array}$ & 4.35 & -3.65 & 11.35 & -10.65 & -1.4 & - & - & - & 1.28 & 1.99 & 8.7 & -10.8 & -1.175 & - & - & - \\
\hline CV(\%) & 1.65 & 3.30 & 0.80 & 0.94 & 2.85 & 2.11 & - & - & 1.33 & 2.06 & 0.48 & 6.16 & 0.45 & 2.69 & - & - \\
\hline LSD (0.05) & 2.60 & 4.74 & 1.35 & 1.23 & 4.21 & 1.32 & - & - & 2.16 & 3.38 & 0.84 & 8.71 & 0.71 & 1.79 & - & - \\
\hline F-test & $* *$ & $* *$ & $* *$ & ns & $* *$ & $* *$ & - & - & $* *$ & $* *$ & $* *$ & ns & $* *$ & ns & - & - \\
\hline
\end{tabular}

$\mathrm{P}<0.05, \mathrm{P}<0.01$, bi $=$ Regression coefficient, $\mathrm{S} 2 \mathrm{di}=$ Deviation from regression 
Table 2. Cont'd.

\begin{tabular}{|c|c|c|c|c|c|c|c|c|c|c|c|c|c|c|c|c|}
\hline \multirow{3}{*}{ Varieties } & \multicolumn{8}{|c|}{ By product yield (t/ha) } & \multicolumn{8}{|c|}{ Cob yield with husk cover (t/ha) } \\
\hline & \multicolumn{5}{|c|}{ Location } & \multirow{2}{*}{ Mean } & \multirow{2}{*}{ bi } & \multirow{2}{*}{$\mathrm{S}^{2} \mathrm{di}$} & \multicolumn{5}{|c|}{ Location } & \multirow{2}{*}{ Mean } & \multirow{2}{*}{ bi } & \multirow{2}{*}{$\mathrm{S}^{2} \mathrm{di}$} \\
\hline & $\mathrm{L}_{1}$ & $\mathrm{~L}_{2}$ & $\mathrm{~L}_{3}$ & $\mathrm{~L}_{4}$ & $\mathrm{~L}_{5}$ & & & & $\mathrm{~L}_{1}$ & $\mathrm{~L}_{2}$ & $\mathrm{~L}_{3}$ & $\mathrm{~L}_{4}$ & $\mathrm{~L}_{5}$ & & & \\
\hline BHM 5 & 30.21 & 43.56 & 30.00 & 40.32 & 46.30 & 38.08 & 1.53 & $0.43 \mathrm{~ns}$ & 7.20 & 8.64 & 10.86 & 5.00 & 15.00 & 9.34 & 1.15 & $0.36 \mathrm{~ns}$ \\
\hline $\mathrm{BBC} 2$ & 30.93 & 26.43 & 25.43 & 30.16 & 37.42 & 30.07 & 0.52 & $17.07 *$ & 6.92 & 5.73 & 11.60 & 4.09 & 12.02 & 8.07 & 0.90 & $5.02 * *$ \\
\hline Khoibhutta & 32.34 & 37.82 & 29.48 & 43.07 & 40.03 & 36.55 & 0.94 & 9.7lns & 7.31 & 10.55 & 8.00 & 5.60 & 15.02 & 9.30 & 1.07 & $1.47^{*}$ \\
\hline NS pop corn & 31.33 & 41.58 & 28.08 & 34.34 & 38.56 & 34.78 & 1.08 & $-0.98 n s$ & 7.59 & 11.58 & 10.44 & 5.41 & 13.63 & 9.73 & 0.97 & $0.38 \mathrm{~ns}$ \\
\hline Shaita & 20.04 & 34.02 & 26.03 & 34.83 & 35.77 & 31.14 & 1.97 & $2.17 \mathrm{~ns}$ & 5.91 & 9.51 & 6.55 & 4.91 & 11.79 & 7.73 & 0.80 & 1.36 \\
\hline BBCI & 28.29 & 36.51 & 24.15 & 35.05 & 36.54 & 32.11 & 1.14 & $-2.60 n s$ & 7.22 & 11.24 & 11.58 & 5.50 & 13.92 & 9.89 & 1.02 & $0.58 \mathrm{~ns}$ \\
\hline BSC1 & 28.19 & 34.44 & 27.95 & 29.05 & 29.35 & 29.79 & 0.36 & $1.17 \mathrm{~ns}$ & 6.62 & 8.21 & 8.49 & 4.25 & 12.22 & 7.96 & 0.90 & $-0.46 n s$ \\
\hline $\begin{array}{l}\text { Pacific283 } \\
\text { (Check) }\end{array}$ & 39.97 & 49.36 & 28.71 & 31.88 & 46.29 & 39.24 & 1.45 & $36.55^{* *}$ & 10.81 & 11.30 & 10.70 & 4.75 & 16.19 & 10.75 & 1.19 & $1.51^{*}$ \\
\hline $\begin{array}{l}\text { Environmental } \\
\text { mean }\end{array}$ & 30.79 & 37.96 & 27.48 & 34.84 & 38.78 & 33.97 & - & - & 7.45 & 9.59 & 9.78 & 4.94 & 13.72 & 9.10 & - & - \\
\hline $\begin{array}{l}\text { Environmental } \\
\text { index (1) }\end{array}$ & -3.18 & 3.99 & -6.49 & 0.86 & 4.81 & - & - & - & -1.64 & 0.497 & 0.68 & -4.15 & 4.62 & - & - & - \\
\hline CV(\%) & 14.39 & 11.27 & 5.69 & 13.76 & 5.18 & 10.81 & - & - & 13.22 & 12.14 & 7.13 & 22.22 & 11.11 & 12.38 & - & - \\
\hline LSD (0.05) & 7.76 & 7.49 & 2.47 & 8.40 & 3.52 & 2.67 & - & - & 1.72 & 2.04 & 1.22 & 1.92 & 2.67 & 0.82 & - & - \\
\hline F-test & $*$ & $* *$ & $* *$ & * & $* *$ & $* *$ & - & - & $* *$ & $* *$ & $* *$ & ns & * & $* *$ & - & - \\
\hline
\end{tabular}

${ }^{*} \mathrm{p}<0.05,{ }^{* *} \mathrm{P}<0.01$, bi $=$ Regression coefficient, $\mathrm{S}^{2} \mathrm{di}=$ Deviation from regression 
In case of days to tasselling, the Khoibhutta was the earliest to flower in 84.20 days after sowing (population mean 85.69 days after sowing) and with bi value smaller than unity and negative $S^{2}$ di values showing its stability and adaptation to unfavourable environments. NS pop corn showed regression coefficient less than one with non-significant deviations from the regression and therefore, well adapted under unfavourable conditions with the predictable performance. BHM5 and BBC2 manifested high mean values and significant deviations from regression, indicating that they were highly sensitive to the environmental changes and performed unpredictably. The genotypes Shaita, BBC1 and Paciflc283 showed significant deviation from the regression indicating non-predictable performance.

In case of days to harvesting, the genotypes Khoibhutta, BBC1, and BSC1 were recorded first harvest at 89.87, 89.33, and 89.47 days, respectively, after sowing (population mean 91.59 days after sowing) and with $b i<\mathrm{l}$ and negative $S^{2}$ di values that showed their stability and adaptation to unfavourable environments. The genotypes BHM5 and BBC2 had a higher mean value and non-significant regression coefficient greater than one indicating that these genotypes will do better in favourable environment. The genotype Shaita had a higher mean value for days to harvesting with regression coefficient significantly lower than unity indicating its suitability to unfavourable environment. The genotype NS pop corn showed regression coefficient greater than unity and hence comparatively well adapted to favourable environment. The genotype Pacific283 manifested high mean values and highly significant deviation from the regression, indicating that they were highly sensitive to the environmental changes and unpredictably.

For by-product, the genotype BHM5 showed higher mean value for yield of by product and non-significant regression coefficient greater than one indicating that this genotype will do better in favourable environment. The genotypes BBC2 and Pacific283 showed significant deviation from regression, indicating nonpredictable performance. The genotype Khoibhutta and NS pop corn were most stable across the environments because they showed higher mean values for yield of by product than the population mean with non-significant regression coefficient very close to unity and non-significant deviation from the regression. The genotypes BBC1, Shaita, and BSC1 were linearly predictable in terms of yield of by product because of non-significant deviation from the regression.

In case of cob yield, the genotypes BHM5, NS pop corn, and BBC1 were most stable across the environments because they showed mean values for cob yield higher than the population mean with non-significant deviation from the regression. The genotypes Khoibhutta and Paciflc283 manifested high mean values and significant deviation from the regression indicating that they were highly sensitive to the environmental changes and unpredictably. The genotypes 
BBC2 and Shaita showed significant deviation from the regression indicating non- predictable performance. The genotype Shaita was linearly predictable in terms of by-product yield because of non-significant deviations from the regression.

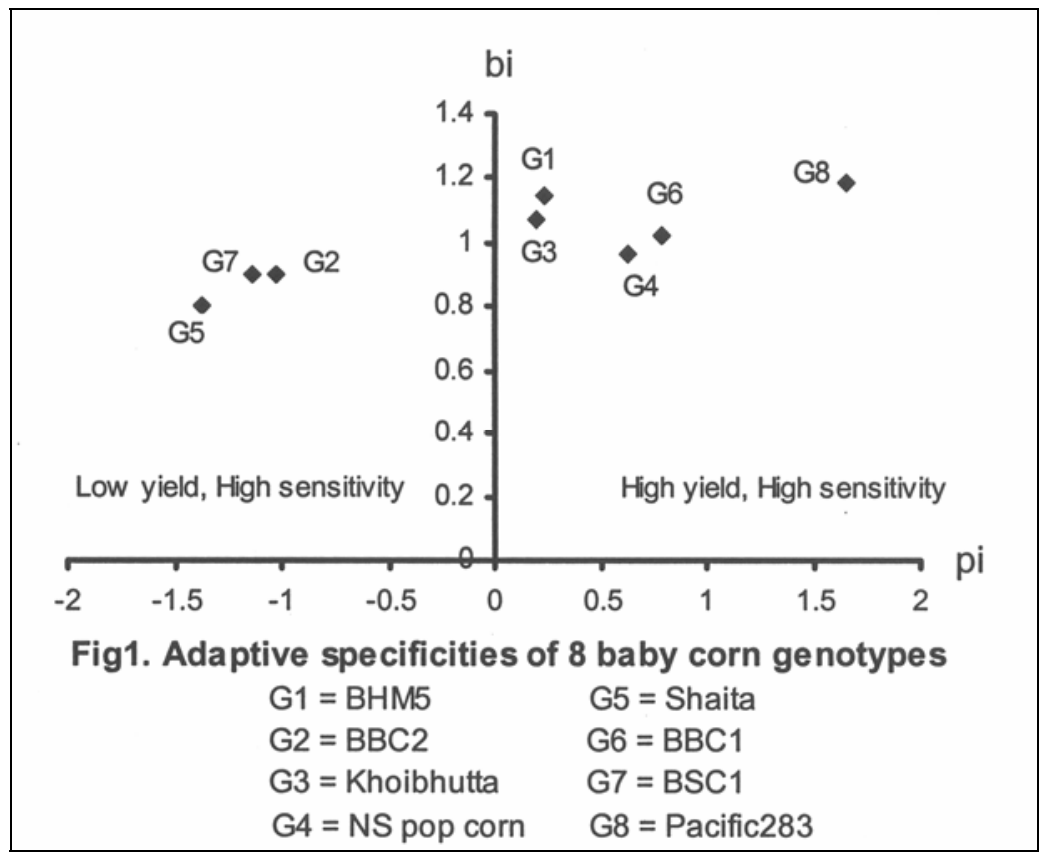

Figure 1 shows the adaptive specificities of eight baby corn genotypes for cob yield, revealing that the genotypes have been categorized into two classes, which are (i) high yield, high sensitivity, and (ii) low yield, high sensitivity. BHM5, Khoibhutta, NS pop corn, BBC1 and Pacific283 have been categorized in the 'high yield, high sensitivity' class having bi and pi values greater than zero. The rest of the genotypes have been classified in the 'low yield, high sensitivity' group having pi value less than zero but bi value greater than zero.

The present study brought out the fact that advantage of genotype may not only be in the area of increased yield, but also for the greater stability in production across the environments. The genotypes Khoibhutta, NS pop corn, and BBC1 showed stability for maximum number of traits, such as days to harvesting of baby cob, yield of baby cob and by product yield. Khoibhutta was stable for days to tasselling, days to harvesting and yield of by product across the environments. Similarly, the genotype BBC1 expressed stability for days to harvesting and cob yield. The genotype NS pop corn was stable for days to tasselling, by-product yield, and cob yield. The BHM5 was stable for cob yield only. These genotypes were superior to other genotypes for per se performance and stability parameters. 


\section{References}

Akanda, M.A.L., M.F. Alam and M.M. Hossain. 2007. Stability analysis of grain yield and its components in maize (Zea mays L.). Bangladesh J. Agric. 32(1): 8 1-89.

Cardoso, M.J., H.W.L. Carvalho, M.L.S. Lea, M.X. Santos, H.W.L. Carvalho and M.X. Santos. 2000. Behavior, adaptability and stability of hybrids of corn in the state of Piaui in the agricultural year of 1998. Revista Cientica Rural. 5(1): 142-149.

Carvalho, H.W.L., M.L.S. Leal, M.X. Santos, A.A.T. Monteiro, M.J.Cardoso, B.C.L. Carvalho, H.W.L Carvalho, M.X. Santos and B.C.L. Carvalho. 2000. Stability of corn cultivars in three ecosystems of Brazilian Northeast. Pesquisa Agropecuaria Brasileira. 35(9): 1773-1781.

Eberhart, S.A. and W.A. Russel. 1966. Stability parameters for comparing varieties. Crop Sci. 6: $36-40$

Guillen-Portal, F.R., W.K. Russel, D.D. Baltensperger, K.M. Eskridge, N.E. D'CrozMason and L.A. Nelson. 2003. Best types of maize hybrids for the western high plains of the USA. Crop Sci. 43: 2065-2070.

Pixley, K.V. and M.S. Bjarnason. 2002. Stability of grain yield, endosperm modification and protein quality of hybrid and open-pollinated quality protein maize (QPM) cultivars. Crop Sci. 42: 1882-1890.

Roy, N.C., Y. Ali, M.R. Ali, S.A. Hussain and M.M. Haque. 1999. Genotype and environment interaction and stability analysis in maize. Bangladesh J. Agril. Res. 24(4): 629-636.

Sharma, B.D. and D.K. Hore. 1991. Stability performance of maize (Zea mays L.) germplasm lines in acidic and phosphorus deficient soils. Indian J. Agric. Sci. 61(12):904-908.

Singh, R.K. and B.D. Chaudhary. 1979. Biometrical methods in quantitative genetic analysis, Kalyani Publishers, Ludhiana, New Delhi. 